\title{
Studi Fenomenologi: Praktik Dan Makna Akuntansi Bagi Wirausahawan Difabel Netra Pada Usaha Mikro
}

\author{
Diska Arliena Hafni ${ }^{1}$ \\ Universitas 'Aisyiyah Yogyakarta \\ diska_kurniawan@yahoo.com
}

\begin{abstract}
The aims of this study is to understand the view about accounting from blind entrepreneurs in micro businesses. Institutional theory is used as a basis for understanding the accounting practiced by blind entrepreneurs. This research is qualitative research with intepretive paradigm and used transcendental phenomenology method. The data obtained through interviews and observations. Stages of data analysis consist of apoche, phenomenology reduction, variation of imagination, and synthesis of meaning and essence. The results showed that the accounting practiced by blind entrepreneurs is in the form of financial records and memory. In this case, blind entrepreneurs prefer to remember rather than record. The meaning contained in accounting practices by blind entrepreneurs in micro businesses leads to the fulfillment of internal business information. It also hinted that accounting is practiced in accordance with the needs and abilities of the users.
\end{abstract}

Keywords: Accounting Practice, Blind Entrepreneurs, Transcendental Phenomenology

\begin{abstract}
ABSTRAK
Studi ini menjelaskan bagaimana akuntansi dipraktekkan oleh wirausahawan yang memiliki difabel netra pada usaha mikro. Teori kelembagaan digunakan sebagai dasar untuk memahami praktik akuntansi yang dipraktikkan oleh wirausahawan tersebut pada usaha mikro. Penelitian ini merupakan penelitian kualitatif dengan paradigma intepretif dan menggunakan metode fenomenologi transendental. Data penelitian diperoleh melalui wawancara dan observasi. Tahapan analisis data terdiri dari apoche, reduksi fenomenologi, variasi imajinasi, dan sintesis makna dan esensi. Hasil penelitian menunjukkan bahwa akuntansi yang dilakukan oleh wirausahawan tersebut adalah dalam bentuk catatan keuangan dan memori. Dalam kasus ini, pengusaha tersebut lebih suka mengingat daripada mencatat. Makna yang terkandung dalam praktik akuntansi oleh pengusaha tersebut di usaha mikro mengarah pada pemenuhan informasi bisnis internal. Ini juga mengisyaratkan bahwa akuntansi dipraktekkan sesuai dengan kebutuhan dan kemampuan para pelaksana.
\end{abstract}

Kata kunci: Praktik Akuntansi, Wirausahawan Difabel Netra, Fenomenologi Transendental 


\section{PENDAHULUAN}

Survei Sosial Ekonomi Nasional (Susenas) tahun 2012 menyatakan bahwa penduduk Indonesia yang menyandang disabilitas sebesar 2,45\%, yaitu sekitar 6.515.500 jiwa dari 244.919.000 estimasi jumlah penduduk Indonesia tahun 2012. Pada konteks lokal Yogyakarta, data Dinas Sosial Daerah Istimewa Yogyakarta menyebutkan bahwa jumlah penyandang disabilitas di DIY mencapai 25.050 orang (jogja.tribunnews.com, 2016). Penyandang disabilitas terbanyak menurut survei tersebut adalah penyandang yang mengalami lebih dari satu jenis keterbatasan (gabungan), yaitu sebesar 39,97\%, kemudian diikuti dengan keterbatasan melihat, dan berjalan atau naik tangga (www.depkes.go.id). Namun demikian, pemetaan berikutnya mendapati bahwa persentase anak tunanetra pada tahun 2013 meningkat hampir dua kali lipat bila dibandingkan dengan tahun 2010 (Mujaddid, 2014).

Pemerintah telah berupaya untuk melakukan pemberdayaan difabel sesuai amanat Undang-undang Nomor 4 Tahun 1997 tentang 'Penyandang Cacat'. Regulasi lain terkait pemberdayaan penyandang difabel ada pada Undang-undang konvensi hak-hak penyandang disabilitas Nomor 19 Tahun 2011. UU Konvensi hak penyandang difabel tersebut mengakui dan mendorong lebih banyak lagi terwujudnya pekerjaan dan lapangan kerja bagi penyandang difabel dalam mendapatkan akses kerja di setiap lembaga kerja. Lebih khusus, Peraturan Daerah Istimewa Yogyakarta Nomor 4 Tahun 2012 pasal 16-40 bagian III ikut menguatkan issue tentang pemenuhan dan perlindungan hak-hak kaum disabilitas.

Rekomendasi temu inklusi 2016 di Kulon Progo Yogyakata, pada topik ketenagakerjaan menyebutkan bahwa dibutuhkan dukungan dari semua pihak untuk penguatan mental dan semangat kerja difabel. Sedangkan rekomendasi temu inklusi pada topik pemberdayaan ekonomi adalah dukungan semua pihak untuk mengembangkan usaha kelompok difabel (temuinklusi.sigab.or.id/2016). Salah satu dukungan yang dapat dilakukan oleh pihak akademisi adalah ikut serta menggali dan mengangkat isu tentang difabilitas menggunakan cara yang lebih ilmiah. Jika menemukan hal positif maka akan menjadi dukungan intelektual bagi penyandang difabel dalam merintis dan meneruskan usaha yang dikelolanya. Namun, jika ditemukan hambatan dan kendala maka dapat dilanjutkan pada penelitian berikutnya atau sekaligus menjadi rekomendasi untuk pihak terkait. Oleh karenanya keilmuan akademisi, khususnya bidang akuntansi, sudah saatnya untuk ikut andil pada pemberdayaan isu difabilitas.

Akuntansi sebagai sebuah ilmu terbukti dapat membantu keberlangsungan usaha mikro. Beberapa penelitian menunjukkan bahwa akuntansi membantu penyediaan informasi untuk memperoleh kredit (Uno, 2009; dan Arif, 2010). Di samping itu, akuntansi juga berpengaruh terhadap kesuksesan usaha (Boyle dan Desai, 1991; Palmer dan Palmer, 2006; dan Mbogo, 2011). Boyle dan Densai (1991) mereviu tiga puluh artikel yang membahas kegagalan bisnis usaha kecil di 
Amerika mulai tahun 1972 sampai 1989. Hasilnya, 9 dari 24 poin penyebab kegagalan usaha kecil terletak pada dampak keuangan. Boyle dan Densai (1991) lebih lanjut menambahkan adanya kebutuhan bagi usaha kecil untuk memperhatikan faktor keuangan yang dapat dikelola melalui akuntansi.

Palmer dan Palmer (1996) meneliti mengenai usaha retail kecil independen di Amerika bagian Tenggara. Penelitian menemukan bahwa pengusaha retail kecil independen yang sukses di Amerika bagian Tenggara mengumpulkan dan menggunakan informasi akuntansi. Perbedaan teknik akuntansi yang digunakan oleh usaha retail kecil independen yang sukses di Amerika bagian Tenggara ratarata terletak pada penyiapan neraca bulanan, penyiapan penilaian binis, penyiapan laporan laba rugi bulanan, perencanaan pajak, penggunaan sistem akuntansi terkomputerisasi, pembandingan gross margin saat ini dengan sebelumya, pembandingan neraca saat ini dengan sebelumnya, penyiapan laporan pro forma, penyiapan laporan kredit, serta penganalisa hasil keuangan.

Mbogo (2011) telah melakukan penelitian mengenai pengaruh praktik dan kemampuan pemilik terhadap kesuksesan dan pertumbuhan usaha kecil menengah di Nairobi, Kenya. Hasil penelitian tersebut menyebutkan bahwa kemampuan akuntansi yang ditandai dengan analisa titik impas, analisa biaya, serta analisa rasio keuangan berpengaruh terhadap kesuksesan dan pertumbuhan usaha kecil menengah di Nairobi, Kenya. Berdasarkan uraian hasil penelitian di atas, dapat ditarik kesimpulan bahwa praktik akuntansi usaha mikro kecil selalu dihubungkan dengan (1) pengelolaan keuangan usaha; (2) angka; (3) unit moneter; (4) perhitungan; serta (5) laporan. Dengan demikian, akuntansi dalam konteks usaha mikro dapat dimaknai sebagai proses pengelolaan keuangan usaha yang bercirikan perhitungan angka dan pembuatan laporan.

Hopwood (1994) sebagaimana ditulis Chariri (2010) menyatakan bahwa praktik akuntansi ditentukan oleh faktor internal dan eksternal yang melingkupinya. Bertolak dari perbedaan usaha mikro dengan usaha lain terutama usaha besar sangat dimungkinkan akan menghasilkan perbedaan praktik akuntansi. Selain itu, pengelolaan keuangan yang dijalankan oleh wirausahawan difabel netra akan memunculkan ciri khas tersendiri atas praktik dan makna akuntansi usaha mikro.

Memandang hal tersebut diatas penelitian tentang praktik usaha mikro yang dijalankan oleh wirausahawan difabel netra sangat layak untuk diangkat. Terlebih Keats dan Bracker (Auken dan Howard, 1993) menyebutkan bahwa usaha kecil adalah entitas unik. Perbedaan karakteristik usaha mikro dengan usaha mikro yang lain sangat mungkin menghasilkan perbedaan praktik akuntansinya, terlebih antara usaha mikro dengan usaha besar. Teori institusional menjelaskan, pada konteks akuntansi yang dipraktikkan oleh organisasi/usaha, akuntansi dibentuk secara sosial oleh individu di dalam dan di luar organisasi/usaha tersebut. 
Faktor lingkungan baik internal maupun eksternal mempengaruhi bangaimana akuntansi dipraktikkan. Oleh sebab itu, penelitian ini menjadikan teori institusional sebagai pijakan untuk menganalisis praktik akuntansi yang dijalankan oleh wirausahawan difabel pada usaha usaha mikro, sehingga nantinya ditemukan sebuah makna akuntansi dari sudut pandang wirausahawan difabel netra itu sendiri. Dipilihnya wirausahawan penyandang difabel netra dengan pertimbangan sejauh mana keterbatasan penglihatan yang dimiliki oleh wirausahawan tersebut mempengaruhi pelaksanaan praktik akuntansi - dalam arti sempit perhitungan dan pencatatan keuangan - yang dijalankan pada bisnisnya, serta makna apa yang terbangun dalam praktik akuntansi tersebut. Dengan demikian, akan diketahui sejauh mana akuntansi sebagai sebuah ilmu dapat berperan atau membantu keberlangsungan usaha mikro bagi wirausahawan difabel netra.

\section{METODOLOGI PENELITIAN}

Penelitian ini merupakan jenis penelitian kualitatif. Menyitir pendapat Sugiono (2007) bahwa penelitian kualitiatif merupakan penelitian yang dilakukan pada kondisi objek alamiah, di mana peneliti menjadi instrumen kunci, teknik pengumpulan data secara trianggulasi, analisa data bersifat induktif, serta hasil penelitian lebih menekankan makna daripada generalisasi. Paradigma yang digunakan dalam penelitian ini adalah paradigma intepretif yakni pemahaman yang mendalam atas realitas apa adanya. Paradigma konstruktivisme (intepretif) memandang ilmu sosial sebagai analisis sistematis atas 'socially meaningful action' melalui pengamatan langsung terhadap aktor sosial dalam setting yang alamiah, agar dapat memahami dan menafsirkan bagaimana aktor sosial mencipta dan memelihara dunia sosial (Salim, 2006).

Ludigdo (2007) mengungkapkan bahwa pentingnya penelitian interpretif dalam akuntansi sebagai upaya untuk memahami suatu konteks praktik profesional yang bersifat kompleks, sehingga bagaimana first-hand knowledge didapatkan secara efektif dari subyek yang diinvestigasi menjadi sangat penting. Untuk itu penelitian ini perlu memperhatikan karakteristik ilmu kemanusiaan. Karena sifatnya yang demikian maka metode yang sangat mendasar dalam ilmu kemanusiaan adalah metode pemahaman (verstehen). Dengan demikian, maka paradigma interpretif lebih tepat digunakan.

Fenomenologi transendental dipilih sebagai metode dalam penelitian ini. fenomenologi transendental atau yang kerap hanya disebut fenomenologi merupakan ilmu mengenai penampakan atau fenomena (Adian, 2010). Fenomena sendiri dijelaskan oleh Kuswarno (2009) sebagai fakta yang disadari dan masuk dalam pemahaman manusia. Dengan demikian, fenomena bukanlah sepenuhnya seperti apa yang tampak secara kasat mata melainkan apa yang masuk dalam kesadaran. 
Hasil akhir penelitian ini berupa penarikan kesimpulan. Kesimpulan dalam penelitian kualitatif merupakan temuan baru yang bisa jadi sebelumnya belum pernah ada. Temuan dapat berupa deskripsi atau gambaran suatu objek temuan yang sebelumnya masih samar-samar atau gelap, sehingga harapannya setelah diteliti menjadi 'terang-benderang' atau jelas. Berdasarkan uraian mengenai rancangan penelitian di atas, maka didapatkan kerangka dan alur penelitian seperti yang diilustrasikan pada gambar 1 .

Gambar 1. Kerangka dan Alur Penelitian

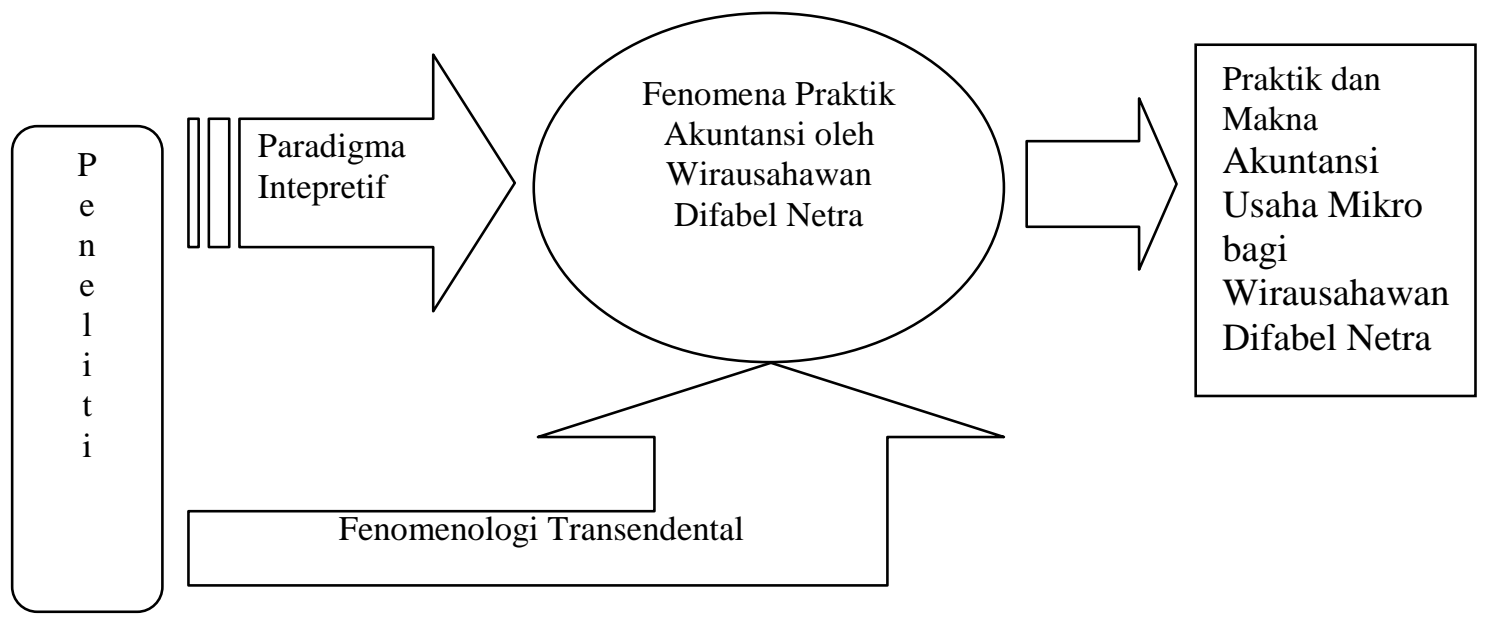

Unit analisis yang digunakan dalam penelitian ini adalah unit analisis individu, yaitu informan. Informan utama penelitian adalah wirausahawan penyandang difabel, netra. Jenis usaha informan adalah pengusaha mikro yang bergerak di bidang jasa atau dagang. Hal ini didasarkan atas pertimbangan bahwa pada umumnya operasional usaha mikro ditangani sendiri oleh pengusaha tersebut. Informan merupakan wirausahawan difabel netra yang menjalankan usaha mikro di Daerah Istimewa Yogyakarta. Informan dipilih dengan metode snowball sampling.

Wawancara dan pengamatan secara langsung dipilih sebagai metode pengumpulan data dalam penelitian ini. Pengumpulan data dilakukan dalam jangka waktu 1 bulan. Analisis data dalam penelitian ini mengikuti sebagaimana analisis data fenomenologi transendental. Mengutip penjelasan Kuswarno (2009), tahapan analisis data fenomenologi transcendental terdiri atas apoche, reduksi fenomenologi, variasi imajinasi, serta sintesis makna dan esensi. Tahapan analisis data dalam fenomenologi transcendental dapat dilihat pada Gambar 2. 
Gambar 2 : Tahapan Analisis Data Fenomenologi Transendental

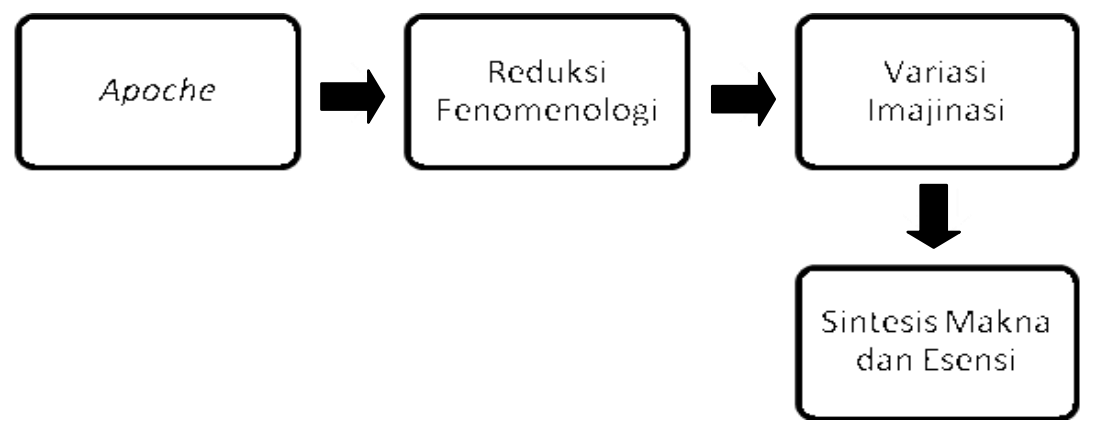

\section{HASIL DAN PEMBAHASAN}

\section{Mandiri Secara Ekonomi di Tengah Keterbatasan Fisik}

Kegiatan usaha merupakan titik tolak untuk memahami praktik akuntansi di suatu perusahaan (Jacobs dan Kemp, 2002). Penelitian ini menelusuri kegiatan usaha yang dijalankan oleh wirausahawan difabel netra. Informan dalam penelitian ini berjumlah tiga orang. Kegiatan usaha yang dijalankan oleh masing-masing wirausahawan difabel netra tersebut bergerak di bidang jasa dan dagang skala mikro. Perusahaan skala mikro dapat didefinisikan sebagai perusahaan dengan ciri kepemilikan kekayaan bersih (tidak termasuk tanah dan bangunan) maksimal Rp 50.000.000 atau penjualan tahunan maksimal Rp 300.000.000.

Informan pertama bernama Trianto menjalankan usaha Panti Pijat Tuna Netra sejak tahun 2012. Informan kedua bernama Hari Pramono menjalankan usaha dagang sandal sejak 2015. Tri Purwanti, informan ketiga berbisnis pulsa sejak tahun 2009. Ketiga informan tersebut mengalami kebutaan sejak lahir. Meski demikian, keterbatasan tidak membuat mereka menutup diri. Terbukti dari tingkat pendidikan terakhir ketiga informan yaitu sebagai sarjana pendidikan.

Hal yang melatarbelakangi ketiga informan menjalankan usaha adalah motif kemandirian ekonomi. Trianto menjalankan usaha di bidang jasa pijat diawali dengan keinginannya yang kuat untuk dapat hidup mandiri. Sebagai penyandang difabel netra, Trianto tidak ingin dianggap lemah juga hidupnya bergantung pada orang lain. Pada tahun 2012 Trianto mencoba menjalankan usaha kecil-kecilan. Ia mulai membuka panti pijat di kontrakannya yang sempit. Keterampilannya memijat ia dapatkan sejak ia duduk di bangku SMA di Surakarta. Alasan membuka usaha dan memilih panti pijat sebagai bisnisnya dikemukakan oleh Trianto sebagai berikut:

"Biasa, kenapa saya kok membuka usaha ini, karena menurut pandangan saya ya, yang pertama saya butuh kemandirian ekonomi. Nah ketika saya bekerja selesai kuliah dan bekerja sebagai guru honorer itu gajinya gak memungkinkan untuk mencukupi hidup. Di jogja. Sehingga saya berpikir, karena dulu saya ketika awal bekerja, saya tinggalnya tinggal di asrama sih. Asrama siswa di Yaketunis. Terdapat 
beberapa fasilitas di sana, tapi kan saya berpikir kalo saya terus tinggal di asrama kapan saya akan memiliki kemandirian ekonomi. Bagaimana saya bisa mengembangkan diri, gitu kan. Dengan gaji yang hanya sekian rupiah gitu kan. Pasti gak bisa lah. Secara nalar manusia. Kemudian saya berusaha untuk berpikir, apa sih kira-kira usaha yang paling mungkin untuk dilakukan dan paling cepat memperoleh uang, nah gitu toh. Akhirnya karena saya berpikir, Ooo ya, dulu saya pernah belajar massage, pijat dan sebagainya, kenapa itu tidak saya gunakan. Akhirnya saya memutuskan dah, 2012 awal itu saya cari-cari kontrakan ternyata dapat. Akhirnya disitulah saya membuka usaha, memberanikan diri".

Saat ini Triyanto sudah memiliki rumah sendiri di daerah Gabusan Bantul. Triyanto membuka praktik jasa pijat di rumahnya seperti yang tampak pada gambar 4.1. Selama satu minggu Triyanto melayani pasien rata-rata 8 orang. Jika pasiennya ramai, dalam sehari Triyanto bisa melayani 4 orang pasien. Terkait modal Triyanto pernah mendapatkan bantuan modal dari LAZIS, BAZNAS dan Yayasan Al-Hikmah. Kisaran bantuan modal yang didapat Triyanto sebesar Rp 2.500.000.

Hal serupa juga dikemukakan oleh Hari Pramono. Sebagai seorang mahasiswa di salah satu perguruan tinggi swasta di Yogya, Hari harus berpikir keras untuk dapat memenuhi kebutuhannya sehari-hari tanpa harus selalu berharap mendapatkan kiriman uang dari orang tuanya. Suatu saat Hari ditawari oleh teman kuliahnya untuk berjualan sandal jepit. Berikut pernyataan Hari Pramono:

"Awalnya, tiba-tiba temen saya menghampiri saya waktu jam kuliah kosong. Terus dia bilang, mau nggak kamu berwirausaha?. Saya bingung waktu itu karena saya tidak punya modal sma sekali. Lalu temen saya bilang kalau dia punya chanel ke pabrik sandal. Jadi tugas saya nanti adalah menjual sandal-sandal itu. Temen saya yang menyuplai sandalnya. Saya langsung mau. Jadi modal saya nol rupiah. Saya juga nggak tahu kenapa teman saya langsung nawari gitu ke saya. Mungkin dia sudah percaya sama saya ya, mbak. Hasil penjualannya lumayan, bisa buat keputuhan saya sehari-sehari. Sekarang juga bisa membantu bayar biaya kuliah." Saat ini Hari mulai mencoba menambah jenis dagangannya berupa kaos kaki, abon, penyedap masakan nonMSG, mie instan tanpa pengawet buatan, sabun cuci piring, pakaian, dan pembersih lantai. Bermula dari modal yang $\mathrm{Rp} 0,-$ Hari memberanikan diri untuk berwirausaha. Hari menggunakan Smartphone program Whatsapp untuk mempromosikan barang dagangannya di grup-grup WA yang dimilikinya. Khusus dagangan sandal jepit, Hari sudah memiliki 5 toko rekanan yang Ia suplai. Hari juga pernah mendapatkan bantuan modal dari Yayasan Al-Hikmah sebesar Rp 5.000.000.

Sedikit berbeda dengan yang dialami oleh Tri Purwanti, keinginannya berjualan pulsa diawali dengan kepandaiannya membaca peluang di lingkungan sekelilingnya. Tri sejak sekolah menengah tingggal di asrama YAKETUNIS. 
Teman-temanya di asrama saat itu hampir semuanya menggunakan Handphone. Jika membutuhkan pulsa, teman-teman Tri harus keluar asrama untuk membeli pulsa. Tri kemudian berinisiatif untuk berjualan pulsa seperti yang dia kemukakan berikut ini:

"Saya waktu itu lihat temen-temen kok hampir setiap minggu beli pulsa. Sudah kayak kebutuhan pokok gitu. Mereka yo harus keluar asrama mbak, kadang malem-malem kalo’ pas butuh telpon keluarga. Kadang kasian nek pas gak dapet pulsanya. Terus saya kepikiran, kenapa saya kok gak jualan pulsa saja ya? Sekalian bantu tementemen. Jadi pas temen-temen butuh, ada gitu tinggal manggil saya, atau tinggal sms, gak perlu keluar-keluar asrama. Terus besoknya saya langsu pergi ke pusat grosir jualan pulsa dianter temen. Saya kulakan pulsa.. Hahahaaa..."

Modal awal yang dikeluarkan Tri di awal menjalankan usahanya adalah sebesar Rp 300.000. Sama halnya dengan Triyanto dan Hari Pramono, Tri Purwanti juga pernah mendapatkan bantuan permodalan. Bantuan modal yang didapatkan oleh Tri yaitu dari BAZNAS sebesar Rp 2.500.000. Sistem usaha pulsa yang dijalankan Tri merupakan sistem deposit. Saat ini jumlah deposit pulsa Tri rata-rata Rp 1.000 .000 per bulan yang Ia dapatkan dari dua tempat pusat grosir pulsa.

\section{Butuh Waktu untuk Mengenali Uang di setiap Transaksi}

Setiap aktivitas bisnis yang kaitannya dengan transaksi jual beli pasti melibatkan uang sebagai alat transaksi. Bagi wirausahawan difabel netra, mengenali nilai nominal uang yang tertera di uang kertas bukanlah hal yang mudah. Saat melakukan wawancara pada masing-masing informal, peneliti sengaja menyodorkan uang kertas Rp 50.000 ke informan. Peneliti meminta informan untuk memegang uang tersebut dan mendekteksi berapa nilai nominalnya. Hanya Triyanto yang berhasil mendetekti dengan benar nilai nominal uang tersebut. Triyanto menggunakan aplikasi pendeteksi yang ada di smartphone-nya. Triyanto terlihat sangat familiar dan lebih terampil dalam menggunakan smartphone dibanding dua wirausahawan lainnya. Namun demikian, Triyanto juga mengakui jika tidak menggunakan aplikasi tersebut Ia merasa kesulitan mendeteksi nilai nominal uang kertas.

Hari Pramono ketika disodori uang Rp 50.000, dia berusaha menggunakan smartphone-nya untuk mendeteksi nilai nominal uang tersebut. Tapi Hari tidak berhasil. Berikut pernyataan Hari Pramono:

"Wah.. susah e mbak... (sambil berusaha mengarahkan smartphonenya sejajar di atas uang kertas). Ini aplikasinya yang lama, jadi uangnya harus difoto dulu terus dimasukkan ke aplikasi baru aplikasinya bisa bicara berapa uangnya. Kalau adik saya yang di Baciro itu punya aplikasi yang baru, gak perlu difoto sudah langsung tau berapa uangnya. Gak tahu saya mbak ini berapa... heheee." 
Begitu juga dengan Tri Purwanti, berikut pernyataannya:

"Piro yo mbak.. Hahahaa... (sambil terus meraba-raba uang tersebut, dalam hal ini Tri tidak menggunakan aplikasi). Rong puluh ewu po yo? Eh. duduk... piro yo? Angel e mbak.. Hahaaaa...”.

Ketika peneliti menanyakan bagaimana cara informan selama ini dalam mengenali nilai nominal uang dari hasil transaksi jual-beli, jika mereka tidak menggunakan aplikasi smartphone, berikut pernyataan Triyanto:

"Biasanya saya tanya sama pasien ketika sudah selesai mijetnya, ini ngasih uang berapa. Lalu mereka ngasih tahu saya".

Pernyataan Hari Pramono:

"Tanya teman atau tanya sama pemilik toko. Saya percaya aja.."

Pernyataan Tri Purwanti:

"Kalau pas di sekolahan saya tanya teman, terus saya tata di dompet yang dalemnya banyak kantong-kantongnya. Saya pisah-pisah dan diurut (dikelompokkan) yang seribuan, dua puluh ribu, lima puluh, seratus (ribu) gitu. Yang saya hafalnya urutan kantongnya. Nek pas di rumah, aku takon karo anake, mbak... Anak saya kan sekarang sudah TK besar, sudah tahu uang. Kebetulan saya dan suami sama-sama tuna netra. Suami buka panti pijat di rumah. Jadi anak saya itu sekarang udah pinter karo duit mbak, sampai seratus ribu dia tahu..."

Informan dulu pernah mendapatkan pengarahan dari BRI yang datang ke YAKETUNIS untuk mendeteksi nilai nominal uang bagi penyandang difabel netra. Berdasarkan informasi dari informan, jika uang kertas masih dalam kondisi baru, mereka bisa dengan mudah mendeteksi uang tersebut. Namun, jika kondisi uangnya sudah lama atau kucel akan susah untuk dideteksi. Hal ini dikarenakan tulisan timbul yang tertera di samping uang kertas teksturnya sudah berubah/rata, sehingga sulit untuk dikenali. Tentu saja hal tersebut akan menghambat proses bisnis yang dijalankan oleh wirausahawaan difabel netra. Mereka sangat bergantung pada aplikasi yang ada di smartphone atau bergantung pada orang lain hanya untuk mengenali nilai nominal uang. Kondisi ini seharusnya mendapatkan perhatian khusus dari pemerintah untuk dapat mencetak uang kertas yang ramah difabel netra. Hal tersebut sebagai salah satu upaya pemerintah untuk mendukung program pemberdayaan ekonomi bagi kaum difabel netra.

\section{Pencatatan Keuangan Mengandalkan Ingatan}

Baik Triyanto, Hari Pramono, maupun Tri Purwanti pernah melakukan pencatatan keuangan. Semua itu untuk laporan pertanggungjawaban ke lembaga-lembaga sosial pemberi bantuan modal. Dinas Sosial DIY selama ini juga telah melakukan pemberdayaan ekonomi bagi kaum difabel netra. Pelaksanaan program pemberdayaan ekonomi bagi kaum difabel netra di atas juga dibarengi dengan sistem pendampingan yang sangat terstruktur. Berikut sistem pendampingan yang dilakukan oleh Dinas Sosial seperti yang dikemukakan oleh Triyanto: 
"Jadi pembinaan itu dilakukan secara berkala. Jadi kalo menurut jadwal, satu bulan sekali ada pembinaan secara bersama. Yang dilakukan di kantor BAZNAS daerah, ada yang di Masjid Diponegoro, balaikota. Kemudian masing-masing kelompok itu kan nanti dikelompokkan karena kemarin kan yang menerima manfaat, istilahnya ya, dari pengucuran dana ini bukan hanya dari temen2 difabel. Ada dari beberapa golongan masyarakat, kemudian dari difabel ada. Kemudian dari ibu-ibu pengajian, dari guru-guru TPA ada juga. Dan (semuanya) mereka dikumpulkan bareng-bareng nanti. Jadi satu, dan satu bulan sekali. Kemudian masing-masing kelompok itu nanti akan didatangi juga sebulan sekali. Ada visit. Ada kunjungan. Ada kelompok YAKETUNIS, ada kelompok ITMI (Ikatan Tuna Netra Muslim Indonesia), dan ada kelompok Al-Hikmah. Jadi untuk tementemen difabel itu. Dan yang lain-lain yang non difabel juga ada (visit di kelompok masing2) kunjungan tersendiri, yang itu dilakukan satu bulan sekali juga. Minimal dalam satu bulan itu terjadi dua kali pertemuan. Yang pertama pertemuan bersama-sama, pembinaan (di masjid diponegoro walikota). Yang kedua pertemuan untuk pemantauan, atau kunjungan untuk memantau usaha yang dilakukan dan juga untuk pemberian motivasi berusaha. Itu kemudian selain itu juga ada, istilahnya, kegiatan menabung. Karena tujuannya agar dananya berkelanjutan kan harus ada tabungan. Makanya tiap bulan harus ada tabungan yang diberikan. Yang nantinya, tiap akhir tahun dana ini akan kembali pada pihak-pihak yang menerima manfaat tadi. Gitu sistem yang dilakukan."

Terkait pencatatan keuangan, Triyanto telah melakukannya. Terlebih hal itu untuk laporan pertanggungjawabannya kepada pihak pemberi bantuan modal yang setiap bulan akan visit ke lokasi usaha. Berikut pernyataan Triyanto:

"Dari wirausahawan harus punya catatan sendiri. Atau paling tidak karena dana yang diperoleh kan tidak terlalu banyak, paling sekitar antara 2,5 sampai dengan 5 (juta). Gak terlalu banyak to. Nah, mereka untuk pembelanjaannya bisa mereka mencatat dengan Braille, atau mereka mencatat di HP, atau ada juga yang hanya diingat-ingat (di otak). Itu untuk kasus yang modalnya diberi oleh orang lain dalam hal ini BAZNAS. Namun Untuk modal sendiri mereka kecenderungannya yang mencatat ini relatif jarang. Jadi budaya tulis menulis, catat mencatat memang belum terbudaya. Belum membudaya istilahnya. Jadi mereka hanya modal berapa digunakan untuk apa, karena modal sendiri kan mereka tidak ada seolah-olah kan tidak ada untuk mempertanggung jawabkan kan. Akhirnya klo mereka ya sudah. Kalau mereka membelanjakan ya dibelanjakan saja, habisnya berapa, 
sekian sekian untuk beli apa, kebutuhannya untuk keberlangsungan usaha mereka. Ada dibelanjakan kemudian kebutuhannya terpenuhi. Tapi memang bagusnya kan harus terstruktur kan. Tertulis. Sehingga terukur."

Pengalaman Hari Pramono di awal-awal menjalankan usahanya, Ia selalu rajin melakukan pencatatan keuangan. Di samping itu, Ia juga melakukan pencatatan jumlah barang dagangannya yang sudah laku maupun yang masih tersisa (stock opname). Tak jarang Hari juga meminta bantuan temannya untuk mencatat keuangan bisnisnya. Namun, akhir-akhir ini Hari sudah tidak melakukan pencatatan lagi, Ia hanya mengandalkan ingatannya untuk mengingat-ngingat berapa uang yang Ia dapatkan dan berapa sisa stok barang dagangan yang masih tersedia. Hari Pramono menyatakannya seperti di bawah ini:

"Iya, dulu saya rajin mencatat mbak.. pakek huruf Braille. Berapa uang yang saya dapet, terus lansung saya masukkan rekening tabungan. Kalok saya habis nganter sandal, saya catet berapa sandal yang saya titipin di masing-masing toko. Tapi lama-lama saya tidak nyatet lagi... karena lama itu lho mbak.. (sambil tersenyum) terus boros di kertas. Kan kalok nulis pake Braille butuh kertas lebih banyak dibanding nulis biasa. Eemm... (terlihat seperti berpikir sejenak) Tapi saya inget kok dari bulan September 2016 sampai sekarang (April 2017) tiap bulannya saya dapet berapa, terus sandalnya ada berapa."

Tri Purwanti dulu pernah melakukan pencatatan keuangan secara rutin ketika dia mendapatkan bantuan dari BAZNAS. Namun, saat ini dia sudah lama tidak melakukan pencatatan. Jenis bisnis yang dilakukannya yaitu jual pulsa dengan sistem deposit lebih memudahkannya mengontrol berapa deposit pulsa yang masih dia miliki. Hal ini juga menentukan kapan Tri harus mengisi deposit kembali. Berikut pernyataan Tri Purwanti:

"Nek jek awal-awal tak cateti mbak.. ijih rajin soale tiap bulan dimonitoring (oleh BAZNAS).. hahaa... sekarang sudah tidak lagi. Kan kalau setiap ada yang beli pulsa, saya langsung dapat informasi dari operator (berupa sms) berapa sisa deposit saya. Kalau depositnya sudah tinggal sedikit, saya cepet-cepet isi lagi. Hasil penjualannya (uang) saya taruh di dompet sendiri (khusus)".

Berdasarkan penjelasan ketiga informan di atas dapat disimpulkan bahwa pencatatan keuangan dilakukan karena adanya tuntutan dari pemberi bantuan modal untuk membuat laporan pertanggungjawaban. Faktor yang menyebabkan tidak dicatatnya setiap transaksi jual-beli adalah budaya catat mencatat bagi para penyandang difabel netra masih sangat lemah. Hal ini dikarenakan menulis dengan huruf Braille membutuhkan waktu yang lebih lama dan membutuhkan lebih banyak kertas. 
Para wirausahawan difabel netra selama ini lebih banyak mengandalkan ingatannya dalam mengelola keuangan bisnisnya. Dalam hal ini, pengelolaan keuangan yang ditandai dengan perhitungan angka-angka untuk pengambilan keputusan dilakukan dalam ingatan para wirausahawan difabel netra. Jam terbang atau pengalaman lebih banyak berbicara dibanding hal-hal teoritis yang harus dilakukan oleh para wirausahawan difabel netra dalam menjalankan usahanya.

\section{Akuntansi di Mata Wirausahawan Difabel Netra}

Pada pembahasan sebelumnya telah diuraikan bahwa para wirausahawan difabel netra saat ini sudah sangat jarang atau bahkan hampir tidak pernah melakukan pencatatan keuangan. Penentuan margin pun mereka tentukan dengan cara yang sederhana yaitu berdasarkan berapa uang yang mereka keluarkan untuk membeli perlengkapan maupun harga pokok penjualan ditambah dengan keuntungan yan mereka inginkan. Semua itu mereka lakukan tanpa ada dasar pencatatan, tapi berdasarkan ingatan mereka saja. Namun demikian, sebenarnya dalam proses penetuan margin mereka sudah cukup memahami yaitu dengan mempertimbangkan biaya-biaya yang melekat pada jasa/barang yang ditawarkan, seperti yang dinyatakan oleh Triyanto berikut:

"Kalo untuk bahan habis pakai yang jelas minyak saja. Minyak yang dibutuhkan. Kalo minyak ini kan relatif irit ya. Misalkan, saya beli satu botol itu 25 ribu. Satu botol sekitar 250 mili liter. Itu bisa digunakan untuk 30 sampai 40 orang. Ada juga minyaknya yang macem-macem, tapi saya lebih suka yang pake massage oil itu. Karena menurut saya kok lebih enak. tadi yang biaya rutin kan hanya bahan habis pakai kan. Hanya minyak. Satu bulan habis satu botol sudah bagus itu. Berarti kan satu botol 25 ribu. Kemudian sama, untuk sabun, untuk nyuci untuk pewangi dan sebagainya saja to. Ya anggarkan lah sektar 20 ribu misalkan. Jadi ya hanya sekitar ya 50 ribu lah. Kan gak terlalu banyak juga. Kalo ditanya penghasilan dari jasa pijat ini, wah itu masih sangat minim mbak. Misalkan saya ratarata ya, misalnya. Satu minggu itu empat orang karena ini kan masih relatif sepi to. Kalo yang rame sehari bisa empat orang. Yang bukanya dari pagi sampe sore, sampe malam, sehari bisa dua-tiga orang sampai empat orang. Tapi kalo saya ini karena hanya seminggu empat orang, jadi satu bulan itu hanya sekitar enam belas orang. Enam belas berarti sekitar delapan ratus (ribu) mbak (dalam satu bulan). Kan kali lima puluh ribu, misalkan dibuat rata-rata to. Ada sih yang empat puluh, ada yang empat puluh lima ribu. Ada yang tiga lima, ada yang tiga puluh. Tapi kan rata-rata lah biar gampang ngitung. Jadi ya sekitar delapan ratus (ribu) gitu aja. Masih sangat kecil. Mikro aja gurem. 
Alhamdulilah. Ya tak sukuri saja lah. Bisa untuk makan, bisa untuk macem-macem lah."

Begitu juga dengan yang dinyatakan oleh Hari Pramono:

"Keuntungan yang saya ambil dari penjualan sandal antara Rp 2.500 sampai Rp 11.000. Kalau yang merk Eiger saya ambil untungnya $R p$ 11.000, laris itu. Biaya transportasi untuk mengantarkan sandal ke toko-toko juga saya pertimbangkan (untuk menentukan margin) karena kalau tokonya jauh, saya harus banyar angkotnya lebih mahal."

Tri Purwanti menentukan marginnya dengan cara yang lebih simpel:

"Prinsip saya ambil untung sedikit ndak apa-apa, yang penting jalan (bisnisnya). Keuntungan yang saya ambil dari penjualan pulsa antara Rp 400 - Rp 500 per transaksi."

Ketika ditanya tentang apa itu akuntansi, berikut jawaban dari masingmasing informan. Triyanto:

"Sistem pembukuan keuangan. Debet-kredit, tapi sekarang saya tidak bisa.. kalau saya dulu di SMA (saya) kan belajar tentang akuntansi juga ya."

\section{Hari Pramono:}

"Pembukuan.. jadi tiap hari dicatat berapa yang dijual, yang dibeli, untungnya berapa."

Tri Purwanti:

"Akuntansi.. Wah mumet kae.. dulu kalau pas ujian kertase nganti duowo.. marai bingung... tapi intinya setiap transaksi jual-beli itu dicatat uangnya gitu ya mbak."

Kemudian peneliti menanyakan apakah dalam menjalankan akuntansi (pencatatan keuangan) itu sulit dan apakah akuntansi itu penting bagi mereka dalam menjalankan usahanya. Mereka menjawab,

Triyanto:

"Sebenarnya (pencatatan keuangan) tidak sulit. Sebenarnya sederhana to. Hal-hal yang sederhana. Tapi Cuma butuh sedikit waktu. Bukan masalah sulit atau gampangnya. Masalah catat mencatat itukan butuh menyisihkan waktu paling sehari lima menit aja cukup.jadwal hari ini ada pasien berapa misalkan lima. itu kan cuman senin, atau rabu sekian tanggal sekian Cuma jumlah pasien pemasukan sekian Cuma gitu aja to. Kan 5 menit cukup. Kebutuhannya juga belum merasa sampai situ, karena pasiennya juga seminggu hanya empat kali. Mungkin kalau nanti usahanya sudah cukup besar, sudah punya karyawan. Nah, itu sangat dibutuhkan."

Hari Pramono:

"Sulitnya itu karena butuh waktu mbak, apalagi nulis pake Braille.

Tapi menurut saya sebenarnya itu sangat penting. Saya merasakannya 
karena sekarang barang dagangan saya semakin banyak dan macemmacem. Kalau tidak dicatat takutnya nanti lupa, bisa kacau. Kalau dicatet kan nanti juga enak bisa tau tiap bulan berapa hasilnya (keuntungan)."

Tri Purwanti:

"Nggak sulit kok, karena dulu waktu SMA pernah diajari. Baiknya memang dicatat ya apalagi kalau transaksinya sudah banyak."

Berdasarkan jawaban ketiga informan di atas dapat ditarik kesimpulan bahwa akuntansi menurut wirausahawan difabel adalah proses pencatatan keuangan terkait transasi jual-beli yang mana catatan tersebut dapat berguna segai kontrol dalam hal ini terkait jumlah persediaan. Catatan tersebut juga berfungsi sebagai sumber informasi seluruh biaya yang dikeluarkan oleh wirausahawan dalam hal ini terkait harga pokok penjualan. Berikutnya, catatan tersebut berfungsi sebagai sumber informasi keutungan usaha. Laba atau yang disebut informan sebagai keuntungan tetap menjadi komponen yang menarik untuk diketahui meskipun tidak dapat dipastikan keakuratan besarannya karena mereka belum melakukan perhitungan secara terperinci.

Tidak ada kesulitan yang berarti yang dihadapi oleh para wirausahawan difabel netra dalam melakukan pencatatan keuangan. Hambatan terbesar terletak pada waktu yang dibutuhkan untuk melakukan pencatatan secara manual. Para wirausahawan difabel netra juga berpendapat bahwa akuntansi penting untuk dilaksanakan dalam suatu bisnis turatama jika bisnis tersebut sudah mulai berkembang, melibatkan banyak transaksi, dan telah memiliki karyawan

\section{KESIMPULAN DAN SARAN}

\section{Kesimpulan}

Akuntansi yang dipraktikkan oleh para wirausahawan difabel netra adalah dalam bentuk catatan keuangan maupun ingatan. Dalam penelitian ini, praktik akuntansi dalam bentuk catatan dilakukan oleh para wirausahawan difabel netra di awal menjalankan usahanya. Hal itu juga didasari oleh sebuah tanggungjawab untuk membuat laporan keuangan yang harus diserahkan kepada institusi pemberi bantuan modal (Dinas Sosial, BAZNAS, LAZIS, dan sebagainya). Namun, saat ini para wirausahawan difabel netra tidak lagi melakukan pencatatan. Hal ini dikarenakan terbatasnya waktu yang dimiliki mengingat pencatatan keuangan dengan Braille membutuhkan waktu yang lebih lama, di samping itu juga membutuhkan kertas yang lebih banyak.

Para wirausahawan difabel netra saat ini hanya mengandalkan ingatannya dalam pengelolaan keuangan bisnisnya. Ketiadaan catatan akuntansi juga ditemui oleh Jacobs dan Kemps (2002) pada pedagang mikro di Bangladesh, di mana perhitungan laba dilakukan dalam ingatan pengusaha, sementara pengendalian atas persediaan dank as dilakukan secara visual dan intuitif. 
Makna yang terkandung dalam praktik akuntansi oleh wirausahawan difabel netra pada usaha mikro mengarah pada pemenuhan informasi internal usaha. Hal ini sekaligus memberikan isyarat bahawa akuntansi dipraktikkan sesuai dengan kebutuhan dan kemampuan pelakunya. Dalam hal ini, para wirausahawan difabel netra lebih suka mengingat daripada mencatat. Pengelolaan keuangan yang ditandai dengan perhitungan angka-angka untuk pengambilan keputusan dilakukan dalam ingatan para wirausahawan difabel netra. Jam terbang atau pengalaman lebih banyak berbicara dibanding hal-hal teoritis yang harus dilakukan oleh para wirausahawan difabel netra dalam menjalankan usahanya.

Karakteristik usaha skala mikro membuat para wirausahawan difabel netra sulit bahkan tidak mungkin untuk memperaktikkan akuntansi umum yang didesain untuk lingkungan perusahaan lainnya yang lebih rumit. Terlebih lagi para wirausahawan difabel netra memiliki keterbatasan penglihatan yang sedikit banyak mempengaruhi kecekatannya dalam melakukan pencatatan keuangan. Dengan demikian, teori institusional dapat menjelaskan bahwa praktik akuntansi yang dijalankan oleh para wirausahawan difabel netra sangat bergantung pada lingkungan di mana, bagaimana dan oleh siapa usaha tersebut dijalankan.

\section{Saran}

Penggalian informasi hendaknya dilakukan pada semua pihak yang terlibat dalam kegiatan usaha para wirausahawan difabel netra (contoh: Instansi pemberi bantuan modal, rekanan, konsumen) sehingga hasil penelitian mencerminkan kondisi utuh yang ada dalam usaha skala mikro yang dijalankan oleh wirausahawan difabel. Pada hasil penelitian ditemukan fakta bahwa para wirausahawan difabel netra dapat mengoperasikan smartphone dan juga laptop yang dilengkapi software khusus penyandang difabel netra. Hal ini dapat menjadi peluang untuk menciptakan suatu sistem akuntansi berbantuan komputer maupun smartphone yang dapat diakses oleh para wirausahawan difabel netra.

\section{DAFTAR PUSTAKA}

Adian, D.G. 2010. Pengantar Fenomenologi. Depok: Penerbit Koekoesan.

Arif, A.2010. Peran Laporan Keuangan dan Intuisi dalam Pengambilan Keputusan Kredit (Studi Empiris Pada Perbankan Kota Semarang). Skripsi. Semarang: Program Sarjana Universitas Diponegoro.

Auken, V., and Howard E. 1993. A Factor Analityc Study of Preceived Causes of Small Business Failure. Journal of Small Bussines Management, October. www.allbusiness.som. Diakses Juni 2013.

Boyle, R.D dan H.B. Desai. 1991. Turnaround Srategies for Small Firms. Journal of Small Business Management, July. www.allbusiness.com. Diakses pada Oktober 2016. 
Chariri, A. 2010. Financial Reporting Practise As A Ritual: Understanding Accounting Within Institutional Framework. Prosiding Simposium Nasional Akuntansi XIII Purwokerto.

Jacobs, K.J Kemp. 2002. Exploring Accounting Presence And Absen: Case studies From Bangladesh. Accounting, Auditing, and Accountability Journal, Vol. 15 no.2, pp. 143-161.

Kuswarno, E. 2009. Metodologi Penelitian Komunikasi Fenomenologi: Konsepsi, Pedoman, dan Contoh Penelitiannya. Bandung: Widya Padjajaran.

Ludigdo, Unti. 2007. Paradoks Etika Akuntan. Yogyakarta: Pustaka Pelajar

Mbogo, M. 2011. Infuence of Managerial Accounting Skills on SME's on the Success abd Growth of Small and Medium Enterprises in Kenya. Journal of Language, Technology \& Entrepreneurship in Africa Vol.3 No.1

Mujaddid. 2014. Kesehatan anak dengan disabilitas. Buletin Jendela Data dan Informasi Kesehatan, Semester II tahun 2014. Hal 25-30.

Palmer, G.D., dan K.N. Palmer. 1996. Accounting, Marketing, and Management Function that Contribute To The Success of The Independent, Small, Rural Retailer. www.sbaer.uca.edu. Diakses pada Oktober 2016

Salim, Agus. 2006. Teori dan Paradigma Penelitian Sosial, Buku Sumber untuk Penelitian Kualitatif Edisi Kedua. Yogyakarta: Tiara Wacana.

Sugiyono. 2007. Memahami Penelitian Kualitatif. Bandung: Penerbit Alfabeta.

Undang-undang Nomor 19 Tahun 2011 tentang CPRD

Undang-undang Nomor 4 Tahun 1997 tentang 'Penyandang Cacat'

Uno, S. S. 2009. Standar Akuntansi ETAP: Kebutuhan dan Tantangan UMKM. Seminar Nasional Akuntansi "Tiga Pilar Standar Akuntansi Indonesia, 17-18 Juli 2009”. Universitas Brawijaya, Malang.

Zachra, E. 2011.Masalah Pembukuan Usaha Mikro Terancam Berantakan. http://swa.co.id. Diakses pada Oktober 2016

www.depkes.go.id diakses pada 17 Oktober 2016

http://temuinklusi.sigab.or.id/2016/unduh-2/ diakses pada 20 Oktober 2016

http://jogja.tribunnews.com/2016/03/18/dinsos-catat-ada-25-ribu-lebih-

penyandang-disabilitas-di-diy/ diakses pada 20 Oktober 2016 